\title{
Fracture Resistance of Simulated Immature Teeth after Different Intra-radicular Treatments
}

\author{
Gustavo Sivieri-Araujo ${ }^{1}$, Mario Tanomaru-Filho², Juliane Maria Guerreiro- \\ Tanomaru², Eduardo Antunes Bortoluzzi ${ }^{3}$, Érica Gouveia Jorge², José Maurício \\ dos Santos Nunes Reis ${ }^{4}$
}

\begin{abstract}
The aim of this study was to evaluate the fracture resistance of simulated immature teeth after different intra-radicular treatments. Crowns and roots of bovine incisors were cut transversally and removed to simulate immature teeth. Root canal preparation and flaring were performed using a bur in crown-apex and apex-crown direction. The samples were distributed into 5 groups $(n=10)$ : Positive control $(\mathrm{PoC})$ - no root canal flaring or filling; Negative control $(\mathrm{NeC})$ - teeth were sectioned and their root canals were flared; Direct anatomical glass fiber post (RaP) - \#2 Reforpost main glass fiber post relined with composite resin; Double tapered conical glass fiber posts (ExP) - \#3 Exacto glass fiber post; and \#2 Reforpost main glass fiber + Reforpin accessory glass fiber posts (RrP). In RaP, ExP and RrP, 4.0-mm apical plugs were done with MTA Angelus. The specimens were embedded in polystyrene resin inside cylinders and the periodontal ligament was simulated with a polyether-based impression material. The specimens were submitted to compressive fracture strength test $\left(0.5 \mathrm{~mm} / \mathrm{min}\right.$ at $135^{\circ}$ relative to the long axis of the tooth) in a servo-hydraulic mechanical testing machine MTS 810 . Data were subjected to one-way ANOVA and Dunnett's C or Tukey's tests $(\alpha=0.05)$. The control groups (PoC and $\mathrm{NeC}$ ) showed lower fracture strength than the experimental groups. $\mathrm{NeC}$ presented the lowest resistance and ExP presented the highest resistance among the experimental groups. The flaring procedures produced a detrimental effect on the fracture resistance of the bovine teeth. Glass fiber intra-radicular posts increased significantly the fracture resistance of simulated immature teeth.
\end{abstract}

\author{
'Department of Dentistry, Araçatuba \\ Dental School, UNESP - Universidade \\ Estadual Paulista, Araçatuba, SP, Brazil \\ ${ }^{2}$ Department of Restorative \\ Dentistry, Araraquara Dental School, \\ UNESP - Universidade Estadual \\ Paulista, Araraquara, SP, Brazil \\ ${ }^{3}$ Department of Restorative Dentistry, \\ UFSC - Universidade Federal de Santa \\ Catarina, Florianópolis, SC, Brazil \\ ${ }^{4}$ Department of Dental Materials \\ and Prosthodontics, Araraquara \\ Dental School, UNESP - \\ Universidade Estadual Paulista, \\ Araraquara, SP, Brazil
}

Correspondence: Prof. Dr. Mario Tanomaru-Filho, Rua Humaitá, 1680, CP 331, 14801-903 Araraquara, SP, Brasil. Tel: +55-16-3301-6391. e-mail: tanomaru@uol.com.br

Key Words: endodontically treated teeth, immature teeth, glass fiber post, fracture resistance.

\section{Introduction}

The use of the intra-radicular posts in immature teeth has been suggested to increase root fracture resistance, allowing for a more favorable prognosis (1). The cementation may be performed with composite resin and self-adhesive resin cements, glass ionomer cement or even mineral trioxide aggregate (MTA) (2-4). MTA may be indicated as an apical plug in the treatment of immature teeth (5), resulting in a faster treatment and inducing the formation of mineralized tissue in the root apex (6).

Several intra-radicular posts and luting agents may be employed to increase the fracture resistance of traumatized immature teeth. As alternatives to metallic post-cores, which have high modulus of elasticity, glass fiber posts exhibit a modulus of elasticity similar to that of the dentin (6). These posts require a specific cement to improve the adhesive characteristics between the post and the root canal walls $(7,8)$.

The glass fiber posts have an elastic modulus similar to that of dentin and may bond adhesively to dentin, withstanding more effectively the tensile stress (9). Use of fiber with or without the filling with composite resin can influence the outcome by increasing the fracture resistance in immature teeth $(9,10)$. More studies are required to establish specific fracture resistance protocols in immature teeth.

The aim of this study was to evaluate in vitro the fracture resistance of bovine incisors in a simulated immature tooth model after different intra-radicular treatments. The tested hypothesis was that the different intra-radicular treatments with glass fiber posts could influence the fracture resistance of immature teeth.

\section{Material and Methods}

Fifty freshly extracted central incisors from young bovines with similar dimensions and straight roots and free of carious lesions, cracks or fractures were selected and disinfected in a $2.0 \%$ glutaraldehyde solution for 15 days and then stored in $0.9 \%$ saline. Using a water-cooled low-speed diamond saw, the crowns and roots were sectioned, respectively, at $8.0 \mathrm{~mm}$ above and $12 \mathrm{~mm}$ below the cementoenamel junction (CEJ) of the labial surface.

Coronal and root pulp was removed using a size 60 Hedström file (Dentsply Maillefer, Ballaigues, Switzerland). Root canals were irrigated with $1.0 \% \mathrm{NaOCl}$ and prepared with a \#703 carbide bur (Jet Beavers Dental Products Ltd., 
Morrisburg, ON, Canada) in crown-apex and apex-crown directions. In this way, an internal root canal diameter of $2.1 \mathrm{~mm}$ was standardized. During these procedures, the teeth were kept in moist gauze. After flaring, buccolingual and mesiodistal radiographs were taken to ensure that the roots had similar dentin wall thickness. Following, the teeth were randomly divided into five groups $(n=10)$.

A 4.0-mm thick apical plug of MTA (Angelus, Londrina, PR, Brazil) was prepared according to Bramante et al. (11). MTA powder and distilled water were was mixed according to the manufacturer's instructions and inserted up to the apical length using a Lentulo spiral while keeping a water-soaked gauze involving the apex to prevent the MTA extrusion. A cotton pellet moistened in distilled water and rolled onto a \#70 K file (Dentsply Maillefer) was used to clean the root canal walls. Radiographs were taken to verify the MTA plug thickness. Once the apical plug was prepared, the following techniques were performed in the root canal:

Positive control (PoC). Teeth were sectioned at $8.0 \mathrm{~mm}$ above and $12 \mathrm{~mm}$ below the CEJ, but no root canal flaring, filling or intra-radicular preparation was performed.

Negative control ( $\mathrm{NeC})$. The teeth were sectioned and their root canals were flared as described above. No filling was performed.

Direct anatomical glass fiber post (RaP). Reforpost main fiber post relined with composite resin was used as an intra-radicular reinforcement. The root canal walls were lubricated with water-soluble gel. Glass fiber posts (1.3 $\mathrm{mm}$ diameter) with parallel shape and retention grooves (\#2 Reforpost; Angelus) were covered with Tetric Ceram (Ivoclar Vivadent) microhybrid composite resin and inserted into root canals. The composite resin was light activated for $10 \mathrm{~s}$ at the cervical root third $(5.0 \mathrm{~s}$ at labial and $5.0 \mathrm{~s}$ at lingual surface) and the post/composite resin set was removed from the canal. After that, the composite resin was additionally light-cured for $60 \mathrm{~s}$ (12).

Double tapered conical glass fiber post (ExP). \#3 Exacto glass fiber posts (Angelus) were used in this group. This post has a 0.05 taper in the medium and cervical thirds and a 0.15 taper in the apical third. The greater cervical diameter (approximately $2.0 \mathrm{~mm}$ ), and double tapering contribute to its well-fitting and passive insertion into the root canal walls.

Reforpost main glass fiber post + Reforpin accessory glass fiber posts (RrP). \#2 Reforpost glass fiber posts $(1.3 \mathrm{~mm}$ diameter) were used as main post and accessory glass fiber posts (Reforpin, Angelus) were used to fill the remaining empty lateral spaces.

Prior to anatomization (RaP) or cementation (ExP and $\operatorname{RrP})$, the posts were cleaned with ethyl alcohol and dried for $60 \mathrm{~s}$. Next, $60 \mathrm{~s}$ after the silane agent application (Angelus), a thin layer of adhesive (Adper Scotchbond
Multi-Purpose; 3M ESPE, St Paul, MN, USA) was applied on the surface of the posts and light-cured (Curing Light $\mathrm{XL}$ 3000; 3M ESPE) for $40 \mathrm{~s}$.

In all experimental groups, root canals were etched with $37 \%$ phosphoric acid for $15 \mathrm{~s}$ and copiously rinsed with distilled water. A controlled drying was made with absorbent paper points. Next, Adper ScotchBond Plus Multi-Purpose adhesive system (3M ESPE, St Paul, MN, USA) was applied on the root canal walls. Adper Scotchbond activator was applied in the root canal using a fine microbrush tip. After drying for $5.0 \mathrm{~s}$, the excess was removed with absorbent paper points. Then, Adper Scotchbond primer followed by the catalyst agent was applied into the root canal in the same manner as described for the activator agent.

After adhesive system application, the posts were cemented with the Cement-Post (Angelus) self-curing resin cement. Following post cementation, new radiographs were taken to evaluate the quality of the root canal fillings. The access cavities were sealed with conventional glass ionomer cement (Vidrion R; SS White, Rio de Janeiro, RJ, Brazil) and the specimens were stored in an incubator at $37{ }^{\circ} \mathrm{C}$ and $100 \%$ relative humidity for $48 \mathrm{~h}$. After this period, to reproduce clinical situation and to provide a more accurate assessment of bovine root fracture strength, the methodology of the present study included periodontal ligament simulation (13). All teeth were embedded in polystyrene resin into polyvinyl chloride cylinders and the periodontal ligament was simulated by a polyether impression material (14).

The teeth were immersed into melted utility wax $2.0 \mathrm{~mm}$ below the CEJ, so that after the wax cooling, an average $0.25 \mathrm{~mm}$ thickness of wax was obtained on the roots. Then, the teeth were embedded in PVC cylinders $(20 \mathrm{~mm}$ diameter $x 25 \mathrm{~mm}$ high), with polystyrene resin mixed according to the manufacturer's instructions. After resin curing, the teeth were removed from the PVC cylinders and the wax eliminated from both the root surface and resin cylinders sockets with warm water. Then, the resin cylinders were filled with polyether-based impression material (Impregum Soft; $3 \mathrm{M}$ ESPE AG, Seefeld, Germany) with a syringe for elastomer material. The teeth were again inserted into their PVC cylinders and the impression material excess was removed with a size 12 scalpel blade. Thus, a simulated $0.25-0.30 \mathrm{~mm}$ thick periodontal ligament from polyetherbased impression material was achieved .

All specimens were subjected to fracture strength testing in a servo-hydraulic mechanical testing machine (810 Material Test System; MTS Systems Corp, Eden Prairie, MN, USA), using a compressive load at a crosshead speed of $0.5 \mathrm{~mm} / \mathrm{min}$ (14). Each specimen was positioned into a cylindrical $(1,15,16)$, which enables the formation of a $135^{\circ}$ angle relative to the long axis of the tooth. These 
procedures were used to simulate a traumatic blow on middle third of the dental crowns from a buccal direction, in agreement with other studies (1).

The ultimate load required to fracture the specimens was recorded in N. Shapiro-Wilk (IBM SPSS Statistics version 20.0, IBM Corporation, Armonk, NY, USA) test was used to test the normality ( $p>0.233)$. Levene's test was applied to test homogeneity of variance. The data were evaluated statistically by one-way (ANOVA; $\alpha=0.05$ ). Dunnett's $C$ post-hoc test was used ( $\alpha=0.05$ ) for pairwise comparisons, evaluating the significant differences among the experimental and control groups. In addition, oneway ANOVA and Tukey's HSD test $(\alpha=0.05)$ were used to compare the experimental groups among them, excluding comparisons with the control groups.

\section{Results}

The fracture resistance values for all pairwise comparisons among the experimental groups and the control groups are shown on Table 1. From the one-way ANOVA and Dunnett's $C$ post-hoc test, it may be observed that the control groups ( $\mathrm{PoC}$ and $\mathrm{NeC}$ ) presented the lowest fracture strength values. The lowest mean value

Table 1. Means of fracture strength $(\mathrm{N})$, standard deviations $( \pm)$, and results of Dunnett's $\mathrm{C}$ test for the pairwise comparisons

\begin{tabular}{lccc}
\hline Groups & Means $( \pm$ SD) & $\begin{array}{c}\mathrm{p} \text { values } \\
\text { Compared with } \\
\text { Positive control }\end{array}$ & $\begin{array}{c}\mathrm{p} \text { values } \\
\text { Compared with } \\
\text { Negative control }\end{array}$ \\
\hline PoC, positive control & $1360.5(200.1)$ & --- & $\mathrm{p}<0.05^{*}$ \\
NeC, negative control & $717.9(176.0)$ & $\mathrm{p}<0.05$ & --- \\
$\mathrm{RaP}$ & $2052.4(190.4)$ & $\mathrm{p}<0.05^{*}$ & $\mathrm{p}<0.05^{*}$ \\
ExP & $2355.3(314.8)$ & $\mathrm{p}<0.05^{*}$ & $\mathrm{p}<0.05^{*}$ \\
RrP & $1893.6(105.6)$ & $\mathrm{p}<0.05^{*}$ & $\mathrm{p}<0.05^{*}$ \\
\hline
\end{tabular}

*Pairwise comparisons with statistically significant results. RaP: Direct anatomical glass fiber post group, ExP: Double tapered conical glass fiber post, RrP: Reforpost main glass fiber post + Reforpin accessory glass fiber posts.

Table 2. Means of fracture strength (N), standard deviations $( \pm)$ and results of Tukey's HSD test for the multiple comparisons among the experimental groups

\begin{tabular}{lcc}
\hline Groups & Mean (N) & SD \\
\hline RaP & $2052.4^{\text {B }}$ & 190.4 \\
ExP & $2355.3^{\text {A }}$ & 314.8 \\
$\operatorname{RrP}$ & $1893.6^{\text {B }}$ & 105.6 \\
\hline
\end{tabular}

Different superscript letters mean statistical differences at $\mathrm{p}<0.05$. RaP: Direct anatomical glass fiber post group, ExP: Double tapered conical glass fiber post, RrP: Reforpost main glass fiber post + Reforpin accessory glass fiber posts. was exhibited by the negative control, where the flaring procedures produced a detrimental effect on the fracture strength of the teeth.

The multiple comparisons among the experimental groups are presented in Table 2. It can be seen that the ExP (double tapered conical glass fiber posts) produced the highest fracture strength values. No significant difference was found between $\operatorname{RaP}$ and $\operatorname{RrP}(p>0.05)$.

\section{Discussion}

The tested hypothesis was accepted. Different intraradicular treatments may influence the fracture resistance of immature teeth and the type of the restorative procedure promotes different fracture resistance.

This study used a simulated immature bovine tooth model according to Bortoluzzi et al. (1). Bovine root dentin has dentinal tubules with similar morphology to those of human dentine (17). The use of bovine teeth has been demonstrated as an alternative to the use of human teeth, and similarity between the mineralized and demineralized dentine matrix of human and bovine teeth was found (17).

Periodontal ligament simulation is important to distribute better the stress generated during the mechanical test $(14,18)$. Different types of intra-radicular posts have been used after production of the MTA plug to reinforce the immature roots of bovine teeth, simulating a clinical situation. The results obtained in bovine teeth were compatible with those of human mature teeth, where the periodontal simulation was performed in vitro (19).

Successful use of MTA as inductive material for apexification by the apical plug construction has been reported (20) in immature teeth. The posterior use of intra-radicular posts aims the root reinforcement (6). The results of this study demonstrated that RaP, ExP and RrP (groups with MTA and glass fiber-reinforced endodontic post) exhibited greater fracture resistance than $\mathrm{PoC}$ and $\mathrm{NeC}$. These results are in agreement with those of previous studies $(1,21)$ employing bovine immature teeth + MTA plug of $4.0 \mathrm{~mm}+$ cementation of either Reforpost metallic post (Angelus Soluções Odontológicas, Londrina, PR, Brazil) or Zirconium Fiber posts (Cosmopost; Ivoclar, Schaan, Liechtenstein). The resin-modified glass ionomer (Vitremer, 3M Dental Products, St Paul, MN, USA) with either Reinforcement Ribbon intra-radicular posts (Connect, Kerr USA, Orange, CA, USA) (6) or Luminex posts (Dentatus AB, Stokholm, Sweden) (5), also demonstrated that the fracture strength increased in freshly extracted immature maxillary central incisors.

According to Signore et al. (22), the prognosis for endodontically treated teeth restored by fiber-reinforced 
posts depends on a wide range of factors, such as post design, length and diameter, luting cement and adhesive system, ferrule height and amount of coronal tooth substance, which have been examined independently or in combination, using in vitro studies or clinical reports. Comparing the groups that received intra-radicular posts, $\mathrm{RaP}$ produced fracture resistance similar to $\mathrm{RrP}$ and lower than ExP. In ExP group, a more homogeneous filling was obtained probably by the use of double tapered conical glass fiber posts. This could be related to the higher values produced by the ExP group compared with the other experimental groups, excluding comparisons with the control groups. These results may be related to the low modulus of elasticity of the fiber posts, generating a smaller load stress, which is uniformly distributed along the post length (22).

Another fact that must be considered is the high amount of coronal tooth substance adopted in this study. Although ferrule was not one of the analyzed factors in the present investigation, it may be speculated that presence of uniform ferrule may have influenced the results. It was seen that the amount of coronal structure may play an - important role in the survival of endodontically treated teeth restored with post-and-core systems (22).

The two experimental groups using Reforpost showed similar results. In RrP, Reforpin fiber glass accessory posts were added to the main fiber glass post Reforpost, without increasing the resistance. Although RaP may have presented a thicker layer of luting resin than $\mathrm{RrP}$, the resistance observed in these groups was similar, agreeing with other studies $(13,23)$. This may be related to the little amount of luting material required to cement the posts, regarding the decrease of empty spaces provided by accessory posts in RrP. The greater diameter of the Exacto fiber post (ExP group) may also have contributed to its results, considering that a good fitting between the post and the root canal walls was obtained. A possible explanation to the differences observed among the results for ExP and Reforpost groups may be related to the presence of a great amount of resin (RaP group) or the empty spaces after the cementation of the main and accessory fiber posts (RrP group). It may be assumed that the insertion of the accessory posts, which present smaller diameter, created empty spaces that were filled by the resin cement. Thus, the cement layer was more prone to present large lacunae or bubbles, reducing the mechanical resistance of the cement-post set and consequently the strength of the restored teeth (23).

Taking into consideration the methodology of this study, the flaring procedures produced a detrimental effect on the fracture resistance of the bovine teeth. Intra-radicular glass fiber posts provide a significant increase in the fracture resistance of flared simulated immature bovine teeth.
When compared with the control groups, double tapered conical glass fiber (ExP) and direct anatomical posts were the best type of reconstruction to restore immature teeth after placement of MTA apical plugs.

\section{Resumo}

0 objetivo deste estudo foi avaliar a resistência à fratura de dentes com rizogênese incompleta simulada após diferentes tratamentos intraradiculares. A rizogênese incompleta foi simulada pelo seccionamento das coroas e raizes de incisivos bovinos. 0 preparo e alargamento do canal radicular foram realizados utilizando uma broca no sentido coroaápice e ápice-coroa. As amostras foram distribuidas $(n=10)$ em cinco grupos: controle positivo $(\mathrm{PoC})$ - sem preparo do canal radicular e sem obturação; controle negativo $(\mathrm{NeC})$ - os dentes foram seccionados e os canais radiculares foram preparados; pino anatômico direto Reforpost \#2 (RaP) - pino de fibra de vidro principal + resina composta; pino de fibra de vidro com dupla conicidade (ExP) - pino de fibra de vidro Exacto \#3; e pino de fibra de vidro Reforpost \#2 + pinos de fibra de vidro acessórios Reforpin (RrP). Nos grupos RaP, ExP e RrP foram realizados plugs apicais de MTA Angelus com $4,0 \mathrm{~mm}$. As amostras foram incluidas em cilindros com resina de poliestireno e o ligamento periodontal foi simulado com material de moldagem à base de poliéter. As amostras foram submetidas ao teste de resistência à fratura, por meio de força compressiva $(0,5 \mathrm{~mm} / \mathrm{min}$ a $135^{\circ} \mathrm{em}$ relação ao longo eixo do dente) em uma máquina de ensaios mecânicos MTS 810. Os dados foram submetidos à ANOVA a um critério e aos testes para comparações múltiplas Dunnett C ou Tukey HSD $(\alpha=0,05)$. Os grupos controle ( $\mathrm{PoC}$ e $\mathrm{NeC}$ ) apresentaram resistência à fratura inferior aos grupos experimentais, sendo o menor valor médio produzido por $\mathrm{NeC}$. ExP produziu os maiores valores de resistência à fratura entre os grupos experimentais. Os procedimentos de preparo e alargamento produziram efeitos prejudiciais na resistência à fratura de dentes bovinos. A utilização de pinos de fibra de vidro intra-radiculares aumentou significativamente a resistência à fratura de dentes com rizogênese incompleta simulada.

\section{References}

1. Bortoluzzi EA, Souza EM, Reis JMSN, Esberard RM, Tanomaru-Filho M. Fracture strength of bovine incisors after intra-radicular treatment with MTA in an experimental immature tooth model. Int Endod J 2007;40:684-691.

2. Rippe MP, Santini M, Bier CA, Borges AL, Valandro LF. Root canal filling: fracture strength of fiber-reinforced composite-restored roots and finite element analysis. Braz Dent J 2013;24:619-625.

3. Dimitrouli M, Geurtsen W, Lührs AK. Comparison of the push-out strength of two fiber post systems dependent on different types of resin cements. Clin Oral Investig 2012;16:899-908.

4. Nothdurft FP, Schmitt T, Motter PJ, Pospiech PR. Influence of fatigue testing and cementation mode on the load-bearing capability of bovine incisors restored with crowns and zirconium dioxide posts. Clin Oral Investig 2008;12:331-336.

5. Shabahang S, Torabinejad M, Boyne PP, Abedi H, McMillan P. A comparative study of root-end induction using osteogenic protein-1, calcium hydroxide, and mineral trioxide aggregate in dogs. J Endod 1999;25:1-5.

6. Park JB, Lee JH. Use of mineral trioxide aggregate in the open apex of a maxillary first premolar. J Oral Sci 2008;50:355-358.

7. Hemalatha H, Sandeep M, Kulkarni S, Yakub SS. Evaluation of fracture resistance in simulated immature teeth using Resilon and Ribbond as root reinforcements - an in vitro study. Dent Traumatol 2009;25:433438.

8. Cauwels RG, Pieters IY, Martens LC, Verbeeck RM. Fracture resistance and reinforcement of immature roots with gutta percha, mineral trioxide aggregate and calcium phosphate bone cement: a standardized in vitro model. Dent Traumatol 2010; 26:137-142.

9. Brito Júnior $M$, Pereira RD, Veríssimo $C$, Soares $C J$, Faria-e-Silva $A L$, Camilo CC, Sousa-Neto MD. Fracture resistance and stress distribution 
of simulated immature teeth after apexification with mineral trioxide aggregate. Int Endod J 2014;47:958-966.

10. Schmoldt SJ, Kirkpatrick TC, Rutledge RE, Yaccino JM. Reinforcement of simulated immature roots restored with composite resin, mineral trioxide aggregate, gutta-percha, or a fiber post after thermocycling. J Endod 2011;37:1390-1393.

11. Bramante $\mathrm{CM}$, Bortoluzzi EA, Broon NJ. Agregado Trióxido Mineral (MTA) como plug para la obturación de conductos radiculares: descripción de la técnica y caso clínico. Endodoncia 2004;22:155-161.

12. Fidel SR, Fidel-Junior RA, Sassone LM, Murad CF, Fidel RA. Clinical management of a complicated crown-root fracture: a case report. Braz Dent J 2011;22:258-262.

13. Clavijo VG, Reis JM, Kabbach $W$, Silva $A L$, Oliveira Junior $O B$, Andrade MF. Fracture strength of flared bovine roots restored with different intra-radicular posts. J Appl Oral Sci 2009;17:574-578.

14. Soares CJ, Pizi EC, Fonseca RB, Martins LR. Influence of root embedment material and periodontal ligament simulation on fracture resistance tests. Braz Oral Res 2005;19:11-16.

15. Melo MP, Valle AL, Pereira JR, Bonachela WC, Pegoraro LF, Bonfante G. Evaluation of fracture resistance of endodontically treated teeth restored with prefabricated posts and composites with varying quantities of remaining coronal tooth structure. J Appl Oral Sci 2005;13:141-146.

16. Pereira JR, Valle AL, Shiratori FK, Ghizoni JS, Melo MP. Influence of intraradicular post and crown ferrule on the fracture strength of endodontically treated teeth. Braz Dent J 2009;20:297-302.

17. Ülker HE, Hiller KA, Schweikl H, Seidenader C, Sengun A, Schmalz G.
Human and bovine pulp-derived cell reactions to dental resin cements. Clin Oral Investig 2012;16:1571-1578.

18. Rees JS. An investigation into the importance of the periodontal ligament and alveolar bone as supporting structures in finite element studies. J Oral Rehabil 2001;28:425-432.

19. Sterzenbach G, Kalberlah S, Beuer F, Frankenberger R, Naumann M. In-vitro simulation of tooth mobility for static and dynamic load tests: a pilot study. Acta Odontol Scand 2011;69:316-318.

20. Albadri S, Chau YS, Jarad F. The use of mineral trioxide aggregate to achieve root end closure: three case reports. Dent Traumatol 2013;29:469-473.

21. Carvalho CAT, Valera MC, Oliveira LD, Camargo CHR. Structural resistance in immature teeth using root reinforcements in vitro. Dent Traumatol 2005;21:155-159.

22. Signore A, Benedicenti S, Kaitsas V, Barone M, Angiero F, Ravera G. Long-term survival of endodontically treated, maxillary anterior teeth restored with either tapered or parallel-sided glass-fiber posts and full-ceramic crown coverage. J Dent 2009;37:115-121.

23. Silva GR, Santos-Filho PC, Simamoto-Júnior PC, Martins LR, Mota AS, Soares $C J$. Effect of post type and restorative techniques on the strain and fracture resistance of flared incisor roots. Braz Dent J 2011;22:230237.

Received August 7, 2014 Accepted March 25, 2015 